\title{
積雪寒冷地にみる崩落表土の播き出し材料としての利 用可能性
}

\section{坂本なつ子 ${ }^{1)} \cdot$ 内田泰三 ${ }^{2) 3}$}

\author{
1）帯広畜産大学大学院畜産学研究科 Grad. Sch. of Agri. Sci., Obihiro Univ. \\ 2) 日本学術振興会 JSPS Res. Fellow \\ 3）帯広畜産大学畜産学部 Obihiro Univ. of Agri. and Vet. Med.
}

\begin{abstract}
摘要：積雪寒冷地における多くの谷では，冬季間に谷壁斜面の積雪が谷底面へと崩れ，堆積する。また，春先の 融雪期には, 谷壁斜面の表土が多分に水分を含み, 前記谷底面の雪上に崩落する（以下，崩落表土）。本研究では, 崩落表土の播き出し利用を目的に，その基礎として崩落表土の成立環境，成分組成ならびに崩落表土からの実生 の出現について検討した。結果は以下の通りであった。崩落表土は傾斜が急で木本が定着し難い立地に多く成立 した。崩落表土はその成分組成から大きく 3 群に類型化され, 無機物を主体とする群, 有機物を主体とする群, ならびに前記両群の中間型に位置する群に特徵づけられた。しかしこれら 3 群の崩落表土において, 播き出し後 の実生の出現種数ならびに総出現個体数に有意な差異はなく，いずれの群においても多数の実生が確認された。 崩落表土からの実生の出現には，播き出し厚さならびに播き出し面積が密接に関係しており，また低温保存の影 響はみられなかった。

キーワード：崩落表土，積雪寒冷地，緑化，播き出し
\end{abstract}

SAKAMOTO, Natsuko and UCHIDA, Taizo: The potential of avalanche soil as a material for revegetation using scattering method in a region with low temperatures and heavy snowfall

Abstract: In a region with low temperatures and heavy snowfall, snow from valley sideslope avalanches builds up on most valley floors. Subsequently in early spring, rain and snowmelt runoff cause debris avalanches that deposit topsoil on the snow; creating "avalanche soil". The avalanche soil does not contribute to the succession of new vegetation in the runoff zone because germination and plant growth are inhibited by the presence of the underlying snow. In this study, the surroundings, composition and germination characteristics of buried viable seeds of avalanche soil were examined using the scattering method. The avalanche soil used was deposited in valleys with steep treeless slopes. Avalanche soil can be classified into three groups based on their composition; mainly organic matter, mainly mineral matter and organic/mineral. After classification, samples of the three groups of avalanche soils were collected and tested using the scattering method. After that, numerous seedlings naturally appeared. The number of species and individuals that occurred were not significantly different among the soil groups. The chance of seedlings sprouting from avalanche soil depends on the thickness of the scattered soil or area covered. Exposure to low temperatures had no effect on the seeds in the soil. Therefore, avalanche soil can be utilized as a new material for the revegetation.

Key words: avalanche soil, region with low temperatures and heavy snowfall, revegetation, scattering

\section{1. 序論}

1995 年の「生物多様性国家戦略」に引き続き，2002 年に は「新・生物多様性国家戦略」が策定されるなど，生物多様 性保全への配慮は不可欠なものとなっている。これは種々 の緑化事業においても同様であり，緑化植物の選定には 生物多様性保全に鑑み, 移入種より自生種の利用が, さらに 自生種においても地域性系統の利用がより強く求められてい

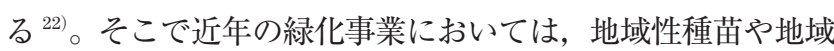
内の表土播き出しが多用される。特に後者においては，土 中に多様な自生種種子が含まれることが多く，生物多様性 保全により鑑みた緑化手法として大きく期待されてい
る $^{4-7,9,11,12,14,15,18,21,23,28-32)}$ 。

他方，積雪寒冷地における多くの谷では，冬季間に谷壁斜 面の積雪が谷底面へと崩れ, 堆積する現象が生じる ${ }^{8)}$ 。また, 春先の融雪期には，谷壁斜面の表土が多分に水分を含み，前 記谷底面の雪上に崩落する ${ }^{1,10,16,17,25)}$ (以下，崩落表土（avalanche soil):写真-1 (I))。これらの崩落表土からは実生が確 認されるが，谷底面に堆積した雪の多くは残雪として初夏ま で融解せず，これは実生の生育期間を短縮あるいはその生育 を阻害する ${ }^{17)}$ 。さらに, 残雪の融解時には崩落表土の多くが 河川へ流出すること（写真-1 (II)）からも自然状態で放置さ れた崩落表土が植生更新に寄与することは稀と考える。しか し，崩落表土からは実生が確認されることから，このような 

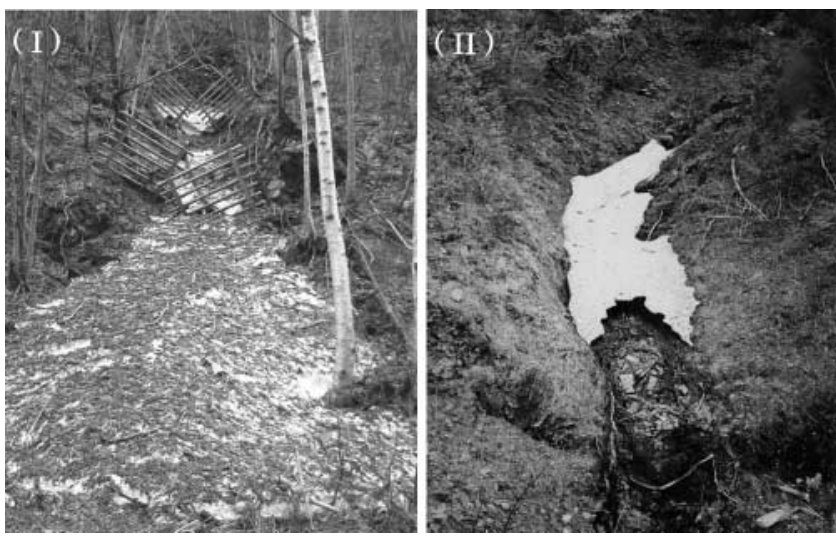

写真-1 積雪寒冷地にみられる崩落表土

（I）谷底面の残雪，崩落表土および雪崩防止柵（写真 中央奥)。(II）残雪の融解と崩落表土の河川への流出。

Photo. 1 Avalanche soil in a region with low temperatures and heavy snowfall. (I) Remaining snow, avalanche soil and snow fence in a valley bottom. (II) Avalanche soil run off as remaining snow melts.

崩落表土を播き出し材料として利活用することは，生物多様 性を考慮した緑化工体系に大きく貢献すると考えられる。

そこで本研究では, 崩落表土の播き出し材料としての利活 用を目的に，その基礎として崩落表土の成立環境，成分組成 ならびに崩落表土からの害生の出現について検討した。さら に, 崩落表土からの実生の出現については, 播き出し面積, 播き出し厚さならびに低温保存との対応からも併せて考察し た。

\section{2. 方 法}

\section{1 調查地の概要}

調查は谷が散在する国道 274 号線日高町内の直線距離 $11 \mathrm{~km}$, 海抜高度 370〜660 m の区間で行った。1/25,000 地形 図と 2003 年 5 月上旬の踏査によって国道から確認できる全 ての谷を調查地とした（図-1）。本地域の気温，積算日照時 間, 積算降水量および最大積雪深は平年值でそれぞれ $5.9^{\circ} \mathrm{C}$, $1,166.9 \mathrm{~h}, 1,312.8 \mathrm{~mm}, 90 \mathrm{~cm}$ であり ${ }^{13)}$, 植生帯は針葉樹林 帯および落葉広葉樹林帯に属し，エゾマツ (Picea jezoensis (Sieb. et Zucc.) Carriére), トドマツ (Abies sachalinensis (Fr. Schm.) Msters）等を主とする針葉樹林および同樹林に ダケカンバ (Betula ermanii Cham.), ケヤマハンノキ (Alnus hirsuta Turcz.）等が混じる針広混交林が成立する ${ }^{3)}$ 。

2.2 調査方法

\section{2 .1 崩落表土の成立環境}

2003 年 5 月上旬, 各調查地を崩落表土の有無から二分し た。次いで二分したそれぞれの調查地について谷幅，海抜高 度，傾斜，方位，植生および構造物の有無を調查した。これ らの項目を二分した調査地間で比較することで，崩落表土の 成立環境について検討した。

各項目の調査は次の要領で 8 月中旬に行った。まず, 谷幅, 海抜高度，傾斜，方位を 1/25,000 地形図から判読した。宗岡

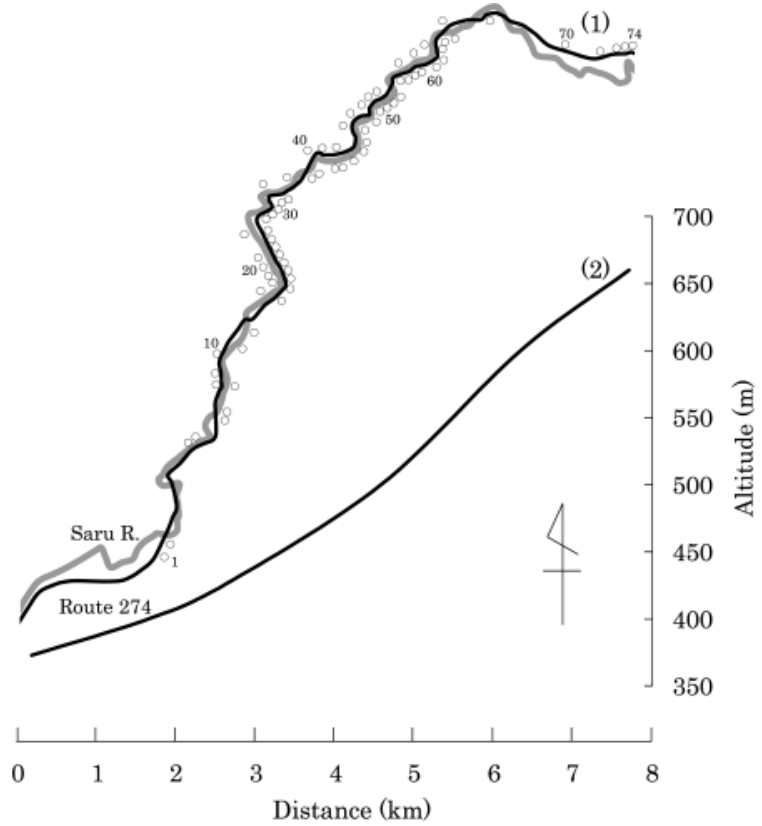

図-1 調査地の概要

(1) : 平面図, (2) : 立面図, $\bigcirc$ : 調查地。図中の数值は 調查地番号を示す (No.1-74)。

Fig. 1 Schematic drawings of study plots. (1): Face view, (2): Side view and $\bigcirc$ : Study plot. Numerical order in figure indicates study plots number (No.1-74).

らの報告 ${ }^{20)}$ に準じて方位から積算日射量の多少を推定し， 各調查地の積算日射量を 4 段階で評価した（北〜北東および 北〜北西: 1 , 北東〜東拉よび北西〜西: 2 , 東〜南東および 西〜南西: 3 南東〜南および南西〜南 : 4)。次いで, 植生は 樹高 $2 \mathrm{~m}$ 以上の木本に着目, 谷壁斜面に $5 \mathrm{~m} \times 10 \mathrm{~m}$ の方形枠 を設置し，同枠内に成立する木本数を記録した。また覆道， 雪崩防止柵および砂防堤を構造物としてその有無を踏査によ り確認した（写真 $-1(\mathrm{I})$ 参照)。

\section{2 .2 崩落表土の成分組成}

2003年 5 月中旬, 上記 2.2 .1 で崩落表土のみられた調査地か ら無作為に 24 調查地点を抽出した。これらの各調查地点に $1 \mathrm{~m} \times 1 \mathrm{~m}$ の方形枠を 1 つ設置し, 同枠内の崩落表土を全て採 取した。採取した崩落表土は $105^{\circ} \mathrm{C}, 96 \mathrm{~h}$ の通風乾燥後, 葉 部, 枝部および土壤に分別, さらに土䁃は地盤工学会 ${ }^{8}$ に準 じて礫，砂㧍よびシルト+粘土に分別後，それぞれを秤量し た。また，土畩は JIS 規格に準じて $750^{\circ} \mathrm{C}, 2 \mathrm{~h}$ で強熱, 強熱 減量を有機物，残渣を無機物として秤量した。

上記の各秤量項目を崩落表土の成分組成とし，これらを変 量に 24 調査地点の崩落表土をクラスター分析（群平均法） により類型化した。

\section{2 .3 崩落表土からの実生の出現}

以下の播き出し試験を带広畜産大学地域共同研究センター 温室内にて適宜灌水, 室温 $25^{\circ} \mathrm{C}$, 遮光 $20 \%$ の環境条件下で 行った。本試験には実生出現法 ${ }^{2)}$ を適用, また全ての播き出 し床には, バーミキュライトを $9 \mathrm{~cm}$ の厚さで用いた。以下の 1）および3）では実生の出現種とその個体数を，2）では実 
生の出現種のみを調査した。

1）崩落表土の播き出し

2003年5月下旬, 上記2.2.2で類型化された各群から無作為 に 3〜 7調查地点を抽出，それぞれの崩落表土を採取した。こ れらは面積 $2,160 \mathrm{~cm}^{2}$, 厚さ $5 \mathrm{~cm}$ で播き出した。崩落表土に 代わってバーミキュライトを播き出すコントロールも同様に 設けた。播き出し期間は 2003 年 5 月下旬〜 10 月下旬とした。

2）面積ならびに厚さを異にした崩落表土の播き出し

2003年5月下旬, 上記2.2.2で類型化された各群から無作為 に 1 調査地点を抽出，それぞれの崩落表土を採取，混合した。 これらは重ねワク法 ${ }^{26)}$ により $22.5 \sim 2,160 \mathrm{~cm}^{2}$ まで 14 段 階の面積を設定，厚さ $5 \mathrm{~cm} ， 5$ 反復で播き出した。

また，1～8 cm まで 8段階の厚さを設け，面積 $720 \mathrm{~cm}^{2}, 3$ 反復で播き出した。これらの播き出し期間は 2003 年 5 月下旬 〜10 月下旬とした。

3）低温保存後の崩落表土の播き出し

上記 2）で採取，混合した崩落表土を 2003 年 5 月下旬〜 2004 年 3 月下旬まで帯広畜産大学内のヒートパイプ型低温賩 蔵庫で低温保存した。保存後の崩落表土は面積 $720 \mathrm{~cm}^{2}$ ，厚 さ $5 \mathrm{~cm} ， 3$ 反復で播き出した。播き出し期間は 2004 年 3 月 下旬〜 8 月下旬とした。保存前の崩落表土を 2003 年 5 月下旬 ～10 月下旬まで播き出すコントロールも同様の面積，厚さ， 反復数で設けた。

ヒートパイプ型低温貯蔵庫とは，ヒートパイプにより形 成させた凍土を農畜産物等の低温貯蔵に利用する施設であ $り^{27)}$ ，本試験で使用したヒートパイプ型低温貯蔵庫内外の月 平均温度および月平均湿度はそれぞれ庫内で $-0.6 \sim 2.5^{\circ} \mathrm{C}$, $58 \sim 80 \%$, 庫外で $-6.0 \sim 18.7^{\circ} \mathrm{C} ， 61 \sim 85 \%$ であった（図-2）。 2.3 群間の差㧍よび独立性の検定

2 群間の差の検定には $t$-検定を，3 群以上の各群間の差の 検定にはボンフェローニの多重 $t$-検定を適用した。また，崩 落表土の有無と構造物の有無との関係については $\chi^{2}$ 独立性 の検定を適用した。有意水準は $p=0.05$ に設定した。

\section{3. 結 果}

\section{1 崩落表土の成立環境}

調査地を崩落表土の有無から二分し，両者の立地条件を 図-3に示した。なお， 74 調查地のうち崩落表土は 44 調查地 で確認され，これは全体数の $59.5 \%$ に達した。

両者において，谷幅，海抜高度掞よび積算日射量に有意な 差異は認められなかったが $(p>0.05)$ ，傾斜および木本数で は有意な差異が認められ $(p<0.001)$, 崩落表土が形成された 立地では，それが形成されない立地と比較して傾斜が急で木 本数は少なかった。

また，崩落表土の有無と構造物の有無とは有意に関係して おり（表-1），崩落表土の形成された立地では，構造物がみ られることが多かった $(p<0.001)$ 。

3.2 崩落表土の成分組成

崩落表土のみられた調査地から無作為に 24 調査地を抽出, これら調査地の崩落表土をその成分組成から類型化した

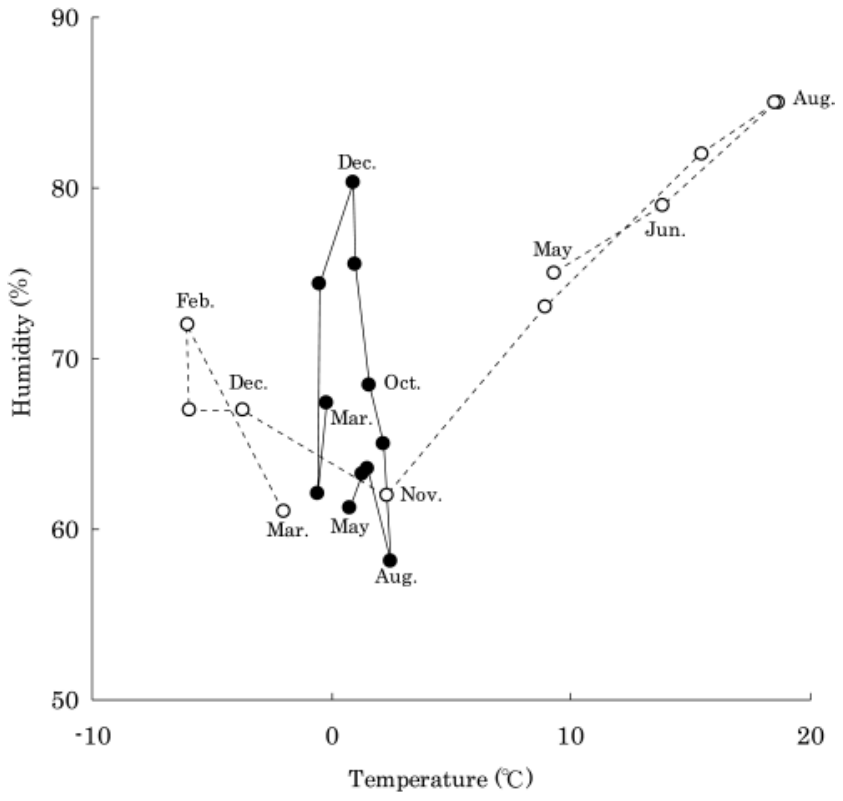

図-2 ヒートパイプ型低温貯蔵庫内外の月平均気温および月平 均湿度

- - : 低温貯蔵庫内, --○-- 低温貯蔵庫外。

Fig. 2 Monthly means of temperature and humidity in and out of low temperature storage room using heat pipe. In, --○--: Out.

(図-4)。最高值の $45 \%$ を区分基準とした結果，崩落表土は群 I，群 II および群 III の 3 群に類型化され，群 I は 13 調査地, 群 II は 8 調查地，群 III は 3 調査地から占められた。

各群における崩落表土の成分組成を表-2に示した。各群で 砂およびシルト＋粘土の量に有意な差異は認められなかっ た $(p>0.05)$ 。これに対して葉部，枝部，礫，総有機物およ び総無機物の量には各群で有意な差異が認められた $(p<0.05)$ 。すなわち，群 I は群 III と比較して葉部，枝部扮 よび総有機物の量が少なく，逆に磼および総無機物の量は多 かった。群 III は群 I と逆の特徴にあり，また，群 II は概ね前 記両群の中間に位置した。

3.3 崩落表土からの実生の出現

3.3.1 崩落表土の播き出し

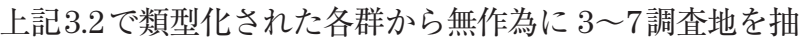
出，これらの崩落表土をそれぞれ播き出した（表-3）。出現 種数ならびに総出現個体数は，それぞれ 5〜35 種，47～565 個体に達した。また，これらに占める移入種の割合は種数で 0.0 9.5\%，個体数では $0.0 \sim 6.3 \%$ であった。

各群における出現種数ならびに総出現個体数の平均はそれ ぞれ，群 I で 22 種，285 個体，群 II では 19 種，322 個体， 群 III では 17 種，162 個体であった。これら各群間の出現種 数ならびに総出現個体数に有意な差異は認められなかった $(p>0.05)$ 。

なお，本試験で確認された実生のうち，北海道レッドデー タブックではメヤブマオ (Boehmeria platanifolia Franch. et Savat.）の 1 種が該当し，当該地指定種ではエゾタツナミ 


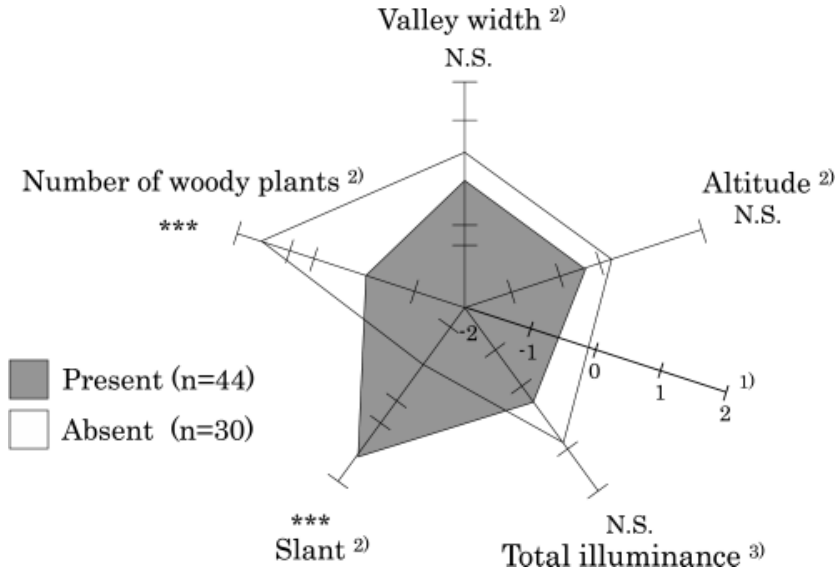

図-3 本調査地における崩落表土の有無とその立地条件 各項目には Z スコアを用いた。軸上の横棒は標準偏差を 示す。 ${ }^{1)}$ 目盛軸。 ${ }^{2}$ スチューデントの $t$-検定。 ${ }^{3)}$ ウルチ の $t$-検定。*** $: 0.1 \%$ 水準で有意差あり, N.S. : $5 \%$ 水準 で有意差なし。

Fig. 3 Surroundings of the study plots distinguished by presence of avalanche soil or not. Z-scores were used in each item. Vertical bars against the axes show standard deviation of the mean. ${ }^{1)}$ Scale for Z-score. ${ }^{2}$ Student's $t$-test was use. ${ }^{3)} W e l c h$ 's $t$-test was use ${ }^{* * *}$ : Significant differences at $0.1 \%$ level. N.S. : No significant differences at $5 \%$ level.

表-1 本調査地における崩落表土の有無と構造物との関係

Table 1 Presence of structures in each plot distinguished by presence of avalanche soil or not

\begin{tabular}{|c|c|c|c|c|c|}
\hline & & \multicolumn{2}{|c|}{ Structure } & \multirow[b]{2}{*}{ Total } & \multirow[b]{2}{*}{$p$-value } \\
\hline & & Present & Absent & & \\
\hline \multirow{3}{*}{ Avalanche soil } & Present & 16 & 28 & 44 & \multirow{3}{*}{$p<0.001^{1)}$} \\
\hline & Absent & 30 & 0 & 30 & \\
\hline & Total & 46 & 28 & 74 & \\
\hline
\end{tabular}

${ }^{1)}$ Using Chi-square for independence test.

ソウ (Scutellaria pekinensis Maxim. var. ussuriensis (Regel）Hand.-Mazz)，エゾノイワハタザオ（Arabis serrata var. glauca Ohwi)，エゾクロクモソウ (Saxifraga fusca Maxim. var. fusca), トモエソウ (Hypericum ascyron L.), オトギリソウ (Hypericum erectum Thunb.)，オニシモッ ケ (Filipendula kamtschatica (Pall.) Maxim.)，エゾノシ ロバナシモツケ (Spiraea miyabei Koidz.) およびカラフト アカバナ (Epilobium glandulosum Lehm. var. asiaticum Hara）の計 8 種か該当した（表-3）。

3.3.2 面積ならびに厚さを異にした崩落表土の播き出し

上記 3.2 で類型化された各群から無作為に 1 調査地点を抽 出，それぞれの崩落表土を採取，混合し，面積ならびに厚さ を異にして播き出した。

崩落表土の播き出し面積と出現種数の関係を図 -5 に示し た。播き出し面積の拡大にともない出現種数は増加の傾向に あるが, 本傾向は播き出し面積 $720 \mathrm{~cm}^{2}$ を境に緩慢に転じた。 崩落表土の播き出し厚さと出現種数の関係を図-6に示した。

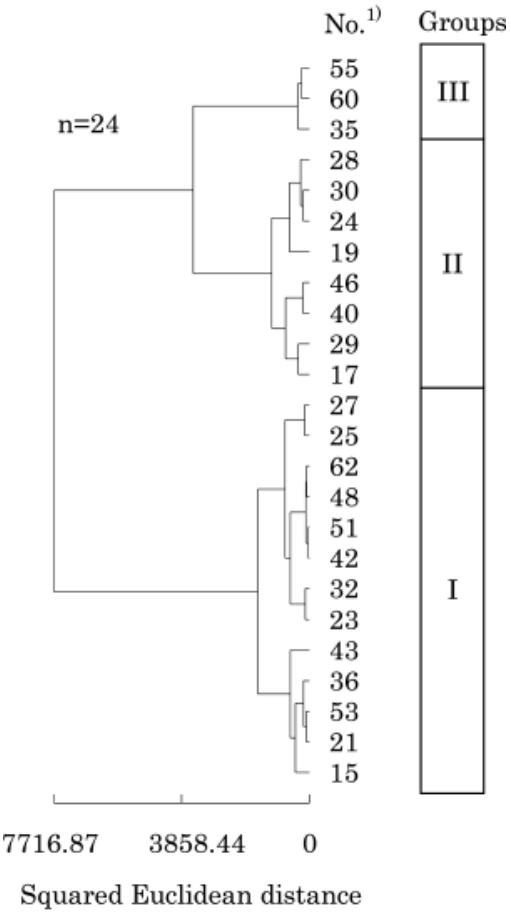

図-4 クラスター分析（群平均法）による調査地の類型化 変量には崩落表土の成分組成を用いた。 ${ }^{1)}$ 図-1 参照。

Fig. 4 Classification among study plots based on their characteristics of avalanche soil using cluster analysis, group average method with squared Euclidean distance. ${ }^{1)}$ See Fig. 1.

表-2 クラスター分析により類型化された各群における崩落表 土の成分組成

Table 2 Characteristics of avalanche soil in each group classified by cluster analysis

\begin{tabular}{|c|c|c|c|}
\hline & Group I ${ }^{1)}$ & Group II ${ }^{1)}$ & Group III $^{1)}$ \\
\hline Items $(\%)$ & $\mathrm{n}=13$ & $\mathrm{n}=8$ & $\mathrm{n}=3$ \\
\hline Leaf & $5.3 \pm 5.1^{2) \mathrm{a}}$ & $8.3 \pm 9.2^{\mathrm{ab}}$ & $17.5 \pm 3.4^{\mathrm{b}}$ \\
\hline Branch & $16.7 \pm 8.3^{\mathrm{a}}$ & $47.3 \pm 10.8^{b}$ & $66.9 \pm 5.6^{\mathrm{c}}$ \\
\hline Gravel & $62.9 \pm 9.5^{\mathrm{c}}$ & $33.5 \pm 6.7^{\mathrm{b}}$ & $5.4 \pm 5.6^{\mathrm{a}}$ \\
\hline Sand & $13.9 \pm 8.4^{\mathrm{a}}$ & $10.1 \pm 5.4^{\mathrm{a}}$ & $9.0 \pm 6.6^{\mathrm{a}}$ \\
\hline Silt and clay & $1.0 \pm 0.7^{\mathrm{a}}$ & $0.7 \pm 0.6^{\mathrm{a}}$ & $0.9 \pm 0.8^{\mathrm{a}}$ \\
\hline Total organic matter ${ }^{3)}$ & $26.6 \pm 11.3^{\mathrm{a}}$ & $61.1 \pm 8.6^{\mathrm{b}}$ & $90.8 \pm 4.1^{c}$ \\
\hline Total mineral matter ${ }^{4)}$ & $73.3 \pm 11.3^{\mathrm{c}}$ & $38.8 \pm 8.6^{\mathrm{b}}$ & $9.1 \pm 4.1^{\mathrm{a}}$ \\
\hline
\end{tabular}

播き出し厚さの増大にともない出現種数は増加の傾向にある が，播き出し厚さ $3 \mathrm{~cm}$ を境に本傾向はみられなくなった。

3.3.3 低温保存後の崩落表土の播き出し

上記 3.2 で類型化された各群から無作為に 1 調査地点を抽 出，それぞれの崩落表土を採取，混合し，これを低温保存前 後で播き出した（図-7)。

崩落表土の低温保存前後における出現種数および総出現個 体数はそれぞれ，保存前では 12 種，58 個体，保存後では 18 種, 53 個体であり, 低温保存前後の出現種数および総出現個 体数に有意な差異は認められなかった $(p>0.05)$ 。 
表-3 クラスター分析により類型化された各群における出現種ならびに出現個体数 ${ }^{1)}$

Table 3 Occurring species and their number in each group classified by cluster analysis ${ }^{1)}$

\begin{tabular}{|c|c|c|c|c|c|c|}
\hline & & & & roup & $\mathrm{I}^{21}$ & \\
\hline & $53^{3}$ & 36 & 23 & 42 & 51 & 48 \\
\hline Occurring species & & & & & & \\
\hline $\begin{array}{l}\text { Woody } \\
\end{array}$ & & & & & & \\
\hline Cercidiphyllum japonicum Sieb. et Zucc. & 38 & 78 & 36 & 156 & 98 & 1 \\
\hline Fraxinus mandshurica Rupr. var. japonica Maxim. & 51 & 29 & 180 & 20 & 79 & 45 \\
\hline Betula ermanii Cham. & 16 & 2 & 7 & 23 & 25 & 20 \\
\hline Alnus hirsuta Turcz. & 6 & 2 & & 46 & 2 & 4 \\
\hline Celastrus orbiculatus Thunb. & 2 & 1 & 90 & & & 4 \\
\hline Actinidia arguta (Sieb. et Zucc.) Planch. ex Miq. & 5 & & 1 & & & 1 \\
\hline Actinidia polygama (Sieb. et Zucc.) Planch. ex Maxim. & & & & 1 & & \\
\hline Sorbus commixta Hedl. & 2 & & 1 & & & 1 \\
\hline Pachysandra terminalis Sieb. et Zucc. & & & & & & 2 \\
\hline Rubus matsumuranus Lév. et Van't. & 1 & & 1 & & & \\
\hline Alnus maximowiczii Call. & & & 4 & & & \\
\hline Picea jezoensis (Sieb. et Zucc.)Carriére & & & & & 1 & \\
\hline Abies sachalinensis (Fr. Schm.) Msters & & & & & & \\
\hline Acer ginnala Maxim. & & & & & & \\
\hline Acer mono Maxim. var. glabrum (Lév. et Van't.) Hara & & & & & & \\
\hline Hydrangea paniculata Sieb. et Zucc. & & & & & & \\
\hline Spiraea miyabei Koidz. ** & & & & & & \\
\hline Taxus cuspidata Sieb. et Zucc. & & & & & 1 & \\
\hline Rosaceae sp. & & & & & & \\
\hline Unknown 1 & & & & & & \\
\hline Unknown 2 & & & & & 2 & \\
\hline Herbaceous & & & & & & \\
\hline Boehmeria platanifolia Franch. et Savat. * & 3 & 4 & 4 & 22 & 3 & 3 \\
\hline Carpesium triste Maxim. & 5 & 1 & 1 & 20 & 37 & 27 \\
\hline Artemisia montana (Nakai) Pamp. & & 2 & 3 & 2 & 1 & 1 \\
\hline Laportea bulbifera (Sieb. et Zucc.) Wedd. & 6 & 13 & & 15 & 17 & 14 \\
\hline Reynoutria sachalinensis (Fr. Schm.) Nakai & 1 & & 1 & 5 & 1 & 1 \\
\hline Clinopodium micranthum (Regel) Hara & 1 & 4 & 2 & 7 & 31 & 3 \\
\hline Eupatorium chinense L. & 3 & & 2 & & 51 & 3 \\
\hline Pilea mongolica Wedd. & & 4 & 5 & 13 & 9 & \\
\hline Scutellaria pekinensis Maxim. var. ussuriensis (Regel) Hand.-Mazz. ** & 1 & & & 1 & 1 & \\
\hline Arabis serrata Franch. et Savat. var. glauca Ohwi ** & & & & 3 & & \\
\hline Aruncus dioicus (Walt.) Fern. var. tenuifolius (Nakai) Hara & & 2 & & 1 & 46 & \\
\hline Stenactis annuus $(\mathrm{L}$.$) Cass { }^{\dagger}$ & & & 3 & & & \\
\hline Thalictrum minus L. var. hypoleucum (Sieb. et Zucc.) Miq. & & & 1 & & & 2 \\
\hline Cacalia auriculata DC. var. kamtschatica (Maxim.) Matsum, & & & & & & \\
\hline Galium trifidum L. var. brevipedunculatum Regel & 1 & & & & 1 & \\
\hline Phryma leptostachya L. ver. asiatica Hara & & & & 2 & & 1 \\
\hline Calamagrostis hakonensis Franch. et Savat. & & & & 1 & & \\
\hline Epilobium glandulosum Lehm. var. asiaticum Hara ** & & & & & 7 & \\
\hline Filipendula kamtschatica (Pall.) Maxim. ** & & & & & 29 & \\
\hline Hypericum erectum Thunb. ** & & & & & & \\
\hline Lactuca raddeana Maxim. var. elata (Hemsl.) Kitam. & & & & & 1 & \\
\hline Melica nutans $\mathrm{L}$. & & & & & & 1 \\
\hline Polygonum aviculare $\mathrm{L}$. & & & & 1 & & \\
\hline Sanicula chinensis Bunge & & & & & & \\
\hline Saxifraga fusca Maxim. var. fusca ** & & & & & 1 & \\
\hline Adenocaulon himalaicum Edgew. & & & & & & \\
\hline Agrimonia pilosa Ledeb. var. japonica (Miq.) nakai & & & & & & \\
\hline Antenoron filiforme (Thunb.) Roberty et Vautier & & & & & & \\
\hline Aster glehni Fr. Schm. var glehni & & & & & 1 & \\
\hline Circaea alpina $\mathrm{L}$. & & & & & & \\
\hline Cirsium kamtschaticum Ledeb. & & & & & & \\
\hline Digitaria violascens Link & & & & 1 & & \\
\hline Elsholtzia ciliata (Thunb.) Hylander & & 1 & & & & \\
\hline Erigeron canadensis $\mathrm{L} .{ }^{\dagger}$ & & & & 2 & & \\
\hline Hylotelephium verticillatum (L.) H. Ohba & & & & & & \\
\hline Hypericum ascyron $\mathrm{L} . * *$ & & & & & & \\
\hline Leontopodium fauriei (Beauv.) Hand. -Mazz. & & & & & & \\
\hline Oenothera biennis L. ${ }^{\top}$ & 1 & & & & & \\
\hline Persicaria nepalensis (Meisn.) H. Gross & 1 & & & & & \\
\hline Picris hieracioides L. subsp. Japonica (Thunb.) Krylov & & & & & & \\
\hline Plantago asiatica $\mathrm{L}$ & & & & 7 & & \\
\hline Senecio cannabifolius Less. & & & & & 7 & \\
\hline Solidago gigantia Alt. var.leiophylla Fernald ${ }^{\dagger}$ & & & & & & \\
\hline Urtica platyphylla Wedd. & & & & & & \\
\hline Chrysosplenium kamtschaticum Fisch. ex Seringe & & & & & 2 & \\
\hline Corydalis ochotensis Turcz. var raddena (Regel) Nakai & & & & & & \\
\hline Compositae sp.1 & & & & & & \\
\hline Compositae sp.2 & & & & & & \\
\hline Cyperaceae sp.1 & & 1 & & & 7 & \\
\hline Cyperaceae sp. 2 & & & & 1 & 4 & \\
\hline Cyperaceae sp.3 & & & & & 4 & \\
\hline Labiatae sp.1 & 2 & & & & & \\
\hline Labiatae sp.2 & & & 1 & & & \\
\hline Labiatae sp.3 & & & 1 & & & \\
\hline Labiatae sp.4 & & & & & & \\
\hline Poaceae sp.1 & & & & & 1 & \\
\hline Poaceae sp.2 & & & & & & \\
\hline Poaceae sp. 3 & & & & & & \\
\hline Unknown 3 & 1 & 4 & & & & \\
\hline Unknown 4 & & & & & & 1 \\
\hline Number of occurring species (No.) & 20 & 15 & 19 & 22 & 29 & 19 \\
\hline Total number of occurring individuals (No.) & 147 & 148 & 344 & 350 & 470 & 135 \\
\hline Ratio of invasive species (\%) ${ }^{4}$ & 5.6 & 0.0 & 5.9 & 4.8 & 0.0 & 0.0 \\
\hline Ratio of invasive individuals (\%) & 0.7 & 0.0 & 0.9 & 0.6 & 0.0 & 0.0 \\
\hline Number of occurring species in each group (No.) & & & & $.6 \pm$ & $4.9^{5) \mathrm{a}}$ & \\
\hline Total number of occurring individuals in each group ( $\mathrm{N}_{\mathrm{N}}$.) & & & & $.1 \pm 1$ & $9.0^{\mathrm{a}}$ & \\
\hline
\end{tabular}




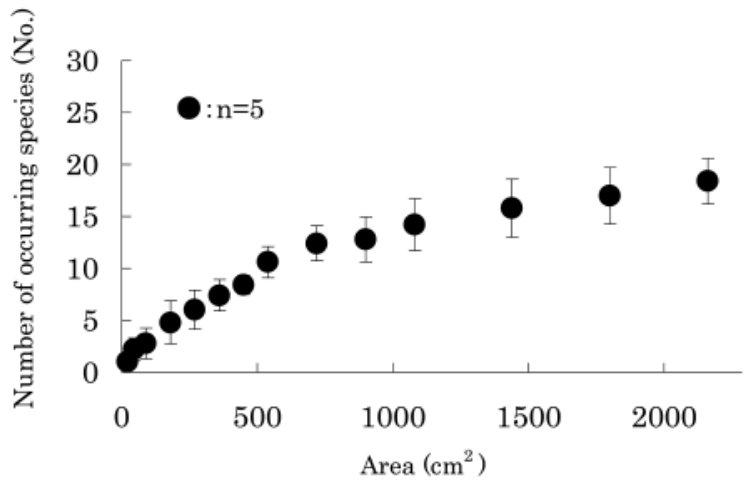

図-5 崩落表土 ${ }^{1)}$ の播き出し面積と出現種数の関係 1) 調査地 No. 15，24 および 60 の崩落表土を混合。播き 出し厚さ： $5 \mathrm{~cm}$ 。縦棒は標準偏差を示す。

Fig. 5 Relation between area of avalanche soil scattered with $5 \mathrm{~cm}$ thick and number of occurring species. Mixture of avalanche soil in study plots No. 15, 24 and 60 was used. Vertical bars show standard deviation of the mean.

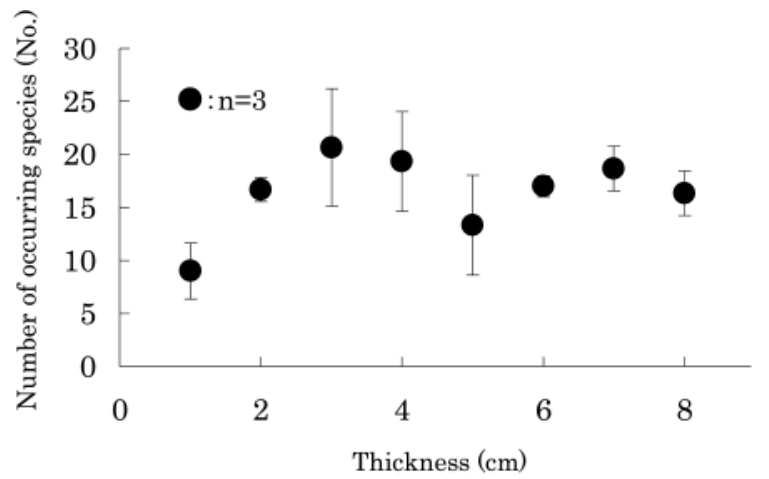

図-6 崩落表土 ${ }^{1)}$ の播き出し厚さと出現種数の関係

1) 調査地 No. 15，24 および 60 の崩落表土を混合。播き 出し面積： $720 \mathrm{~cm}^{2}$ 。縦棒は標準偏差を示す。

Fig. 6 Relation between thickness of avalanche soil scattered in $720 \mathrm{~cm}^{2}$ and number of occurring species. Mixture of avalanche soil in study plots No. 15, 24 and 60 was used. Vertical bars show standard deviation of the mean.

\section{4. 考 察}

4.1 崩落表土の成立環境ならびに成分組成

崩落表土は傾斜が急な立地, 木本数が少ない立地, 構造物 がみられる立地の多くで成立することが示された（図-3, 表-1)。すなわち，傾斜が急で木本が定着し難い立地に崩落 表土は成立し易いと考えられ，これは急斜面かつ植生が成立 し難い立地で雪崩や土砂崩落が生じ易いとするこれまでの雪 水学・地盤工学的研究 $1,10,16,17,19,25)$ と一致するところである。 また，構造物のみられる立地の多くで崩落表土が成立したこ とから, 構造物の有無は, 崩落表土の成立する立地をみつけ る上で一つの指標になると考えられた。これは元来，構造物
の設置目的が雪崩や土砂崩落の予防措置であり，このように 構造物が設置される立地では必然的に崩落表土も成立し易い ためと考える。

他方, 崩落表土はその成分組成から群 I, 群 II および群 III の 3 群に分けられた（図-4)。これら各群は, 崩落表土に含ま れる葉，枝等の有機物および土䁃中の有機物，無機物の割合 から（表-2），無機物を主体とする群 I，有機物を主体とする 群 III, ならびに無機物, 有機物の量が前記両群の中間に位置 する群 II に特徴づけられると考える。しかし, 各群間の出現 種数ならびに総出現個体数に有意な差異は認められず（表3), いずれの群からも多数の実生が確認された。これは崩落 表土がダムや砂防堤等に堆積する土壤と同様に広範囲から集 積したものであり, 崩落表土の成分組成の違いに関わらず多 様な種子が集積されるためと考えた。

4.2 既往の播き出しからみる崩落表土の位置づけ

崩落表土からの実生の出現種数ならびに総出現個体数は, 播き出し面積 $2,160 \mathrm{~cm}^{2}$ ，播き出し厚さ $5 \mathrm{~cm}$ でそれぞれ 5 〜 35 種，47〜 565 個体であった（表-3）。後者を $1 \mathrm{~m}^{2}$ (播き出し 厚さ $5 \mathrm{~cm}$ ）あたりに換算した值は平均で 1,263 個体となる。 既往の森林表土播き出しでの実生の総出現個体数は，今橋・ 熟谷（1996）の 5,896 個体 $/ 15 \mathrm{~L}^{7}$, 細木ら（2001）の 726 個 体 $/ 40 \mathrm{~L}^{6}$, 細木ら (2004) の 13.2 35.4 個体/ $/ \mathrm{L}^{5}$ 等が報告さ れている。これらの值を先と同様に $1 \mathrm{~m}^{2}$ (播き出し厚さ $5 \mathrm{~cm})$ あたりに換算するとそれぞれ 19,653 個体, 908 個体お よび $660 \sim 1,770$ 個体となる。崩落表土からの実生の総出現 個体数をこれら既往の報告と比較すると, 崩落表土での值は 既往の報告の範囲内にあると考える。また，実生の出現種数 は, 一般に総出現個体数のように換算できないため, 他の結 果と安易に比較はできないが, 崩落表土からの実生の出現種 数は緑化資材として決して少なくない数と筆者らは考える。

森林表土や低湿地表土 ${ }^{9,18,21)}$ での播き出し面積と出現種数 との関係においては, 播き出し面積の拡大にともなう出現種 数の増加がある面積を境に飽和もしくはそれに近づく形をと る。また崩落表土に拈いては, 播き出し面積の拡大にともな う出現種数の増加が播き出し面積 $720 \mathrm{~cm}^{2}$ を境に緩慢に転じ (図-5)，これは既往の報告と同様の形をとるといえる。

崩落表土の播き出し厚さと出現種数の関係は, 播き出し厚 さの増大にともない出現種数も増加の傾向にあるが, 播き出 し厚さ $3 \mathrm{~cm}$ を境に本傾向はみられなくなった（図-6)。これ は, 森林表土の播き出しに $4 \mathrm{~cm}$ が最適とされ， $5 \mathrm{~cm}$ 以上で 種数が増加しないとする報告 ${ }^{28,29,32)}$ に概ね一致する。

以上，崩落表土の播き出しはこれまでの表土播き出しと比 較して, 実生の出現においてその特性（総出現個体数, 播き 出し面積および播き出し厚さと出現種数との関係) がよく類 似すると考える。したがって, 崩落表土は, 既往の表土播き 出しと同様に今後の緑化資材として期待できると考えた。ま た, 森林表土とは異なり, 崩落表土の採取は春先から初夏ま での短期間に制約されるが, 崩落表土の低温保存前後におけ る出現種数および総出現個体数に有意な差異は認められない ことから (図-7), 崩落表土の低温保存は可能といえ, これ 

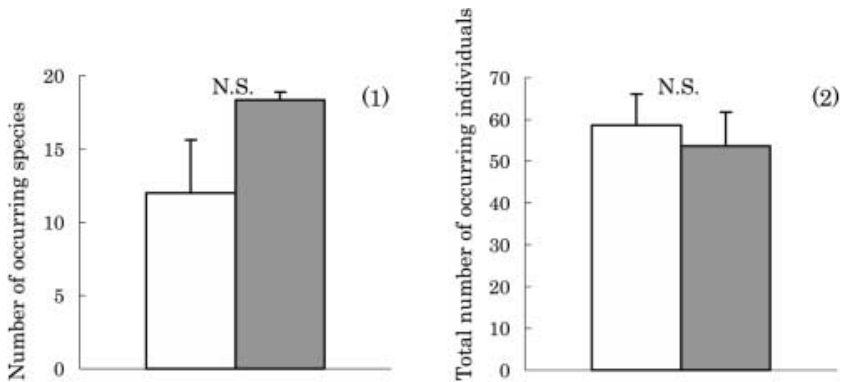

図-7 崩落表土 ${ }^{11}$ の低温保存前後における出現種数（1）および 総出現個体数 (2)

1) 調査地 No. 15，24 および 60 の崩落表土を混合。播き 出し面積: $720 \mathrm{~cm}^{2}$ 。縦棒は標準偏差を示す $(n=3)$ 。 N.S.: $5 \%$ 水準で有意差なし（スチューデントの $t$-検定）。 $\square$ : 保存前 (コントロール)， $\square$ : 保存後。

Fig. 7 Number of occurring species (1) and their total number of individuals (2), before and after low temperature storage of avalanche soil for ten months. Mixture of avalanche soil in study plots No. 15, 24 and 60 was used. Avalanche soil was scattered in $720 \mathrm{~cm}^{2}$. Vertical bars show standard deviation of the mean $(n=3)$. N. S.: No significant differences at $5 \%$ level using student's $t$ test. $\square$ : Before (control), $\square$ : After.

により先の制約も解消できると考えた。さらに梅原・永野 （1997）は，森林表土の野外での積みあげ保存が可能である としていることから ${ }^{28)}$ ，崩落表土においても低温保存に加え て，より簡便な野外での積みあげ保存の可能性も示唆されよ う。

4.3 生物多様性保全からみる崩落表土の播き出し利用

播き出しに対する目的は多様化の一途にあり，生物多様性 保全，未利用·低利用資源の利活用（例えば浚渫土壤），ゼロ・ エミッション（例えば建設廃土）など多岐にわたる なかでも，生物多様性保全への配慮が強く唱われる現在 ${ }^{22)}$, 各目的においても播き出し後に出現する貴重種および自生種 の定性的，あるいは定量的評価は不可欠といえる。

本論が提唱する崩落表土の播き出しにおいて環境省のレッ ドデータブックでの指定種は確認されなかったが, 北海道 レッドデータブックの指定種からは 1 種, 当該地指定種から は 8 種の実生が確認された（表-3）。また, 崩落表土から出現 した実生のうち移入種の占める割合は種数で $0.0 \sim 9.5 \%$, 個 体数では 0.0 ６.3\% であり（表-3），これらの值は既往の播 き出し ${ }^{4-6,14,32)}$ を大幅に下回るものであった。したがって，少 なくとも本調査地における崩落表土の利用は，生物多様性保 全に大きく寄与し，新たな緑化資材として利活用できるもの と考えた。

\section{4 今後の課題と展望}

崩落表土は調査対象地の $59.5 \%$ で確認されたが（図-3, 表-1)，同值に対しては評価し難い。また，これまでに報告さ れる播き出し 5,9,11,18,21) と同様に, 崩落表土においても採取地, 採取時期，施工地，施工法等によって播き出し後の成立植生 は大きく異なると予想され，これらの点においては更なる検
討が要される。播き出しに資するこれまでの研究では播き出 し後の成立植生と周辺植生との対応が重視されるが ${ }^{4-6,21)}$, ダ 厶や砂防堤等に堆積する土壤と同様に崩落表土も広範囲から 集積するものと考えられ, 崩落表土の播き出し後の成立植生 と周辺植生との対応については表土の供給源を広域的に捉え た調査が今後に求められる。

最後に, 本研究の遂行にあたりご䩿撻を賜りました株式会 社ズコーシャ総合科学研究所明石憲宗氏に梁く感謝の意を表 するとともに, 厚く御礼申し上げます。また, 調査の実施に ご尽力頂きました帯広畜産大学丸山純孝名誉教授, 同大学佐 藤雅俊教官ならびに，ヒートパイプ型低温貯蔵庫に関する資 料を提供して頂きました同大学土谷富士夫教授には，この場 を措りして厚く御礼申し上げます。

\section{引用文献}

1) Fahey, B. D. (1974) Seasonal frost heave and frost penetration measurements in the Indian Peaks region of the Colorado Front Range. Arct. Alp. Res., 6: 63-70.

2）浜田 拓・倉本 宣 (1994) 実生出現法によるコナラ林の 埋土種子集団の研究抢よびその植生管理への応用, ランド スケープ研究, 58(1): 76-82.

3）北海道生活環境部自然保護課（1979）日高山系現存植生 図, 北海道.

4）細木大輔・米村惣太郎・亀山 章（2000）埋土種子を用い て緑化した法面植生の推移, 日本緑化工学会誌, 25: 339344.

5）細木大輔・米村惣太郎・亀山 章 (2004) 関東の土壌シー ドバンクに㧍ける緑化材料としての利用可能性とその測定 方法, 日本緑化工学会誌，29: 412-422.

6）細木大輔 - 吉永知恵美 - 中村勝衛 - 龟山 章 (2001) 森林 表土を用いた法面緑化で成立する植物群落の特性，日本緑 化工学会誌, 27: 114-119.

7）今橋美千代・熟谷いづみ（1996）土䁃シードバンクを用い た河畔冠水草原復元の可能性の検討，保全生態学研究，1: 131-147.

8）地盤工学会土の試験実習書編集委員会（2000）土質試験一 基本と手引き一, 社団法人地盤工学会, $251 \mathrm{pp}$.

9）陣門泰輔・佐藤治雄・森本幸裕（2000）森林表土播きだし による荒廃地緑化に関する研究，日本緑化工学会誌，25: 397-402.

10）梶本卓也 - 大丸裕武 - 杉田久志（2002）雪山の生態学，東 京大学出版会, $289 \mathrm{pp}$.

11）柏原一凡・佐藤治雄・森本幸裕（2000）畦畔表土利用によ る植生回復の初期状況一福井県中池見の法面緑化を事例と して一, 日本緑化工学会誌, 25: 379-384.

12）柏木 亨 - 吉田博宣 - 勝野武彦（2003）落葉落枝層を活用 した樹木種子の出芽と実生の成長過程, 日本緑化工学会 誌, 29: 223-226.

13）気象庁気象業務センター（2004）電子閲覧室: 気象庁ホー ム ペー ジ http://www.data.kishou.go.jp/, 2004.7.7 更新, 2004.7.12 参照 .

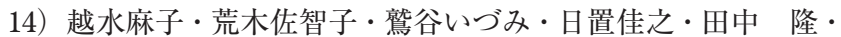
長田光世（1997）土㙵シードバンクを用いた谷戸植生復元 に関する研究，保全生態学研究，2: 189-200.

15) Madsen, C. (1986) Wetland restoration: a pilot project. J. 
Soil Water Conserv., 41(3): 159-160.

16）松井 健・武内和彦・田村俊和（1990）丘陵地の自然環境 一その特性と保全一, 古今書院, $202 \mathrm{pp}$.

17) Matsuoka, N. (1994) Continuous recording of frost heave and creep on a Japanese alpine slope. Arct. Alp. Res., 26: 245-254.

18）水澤 智・中本 学・森本幸裕 (2000) 土壤シードバンク による低湿地植生復元に関する研究, 日本緑化工学会誌, 25: 321-326.

19) Mooney, H. A. and Billings, W. D. (1960) The annual carbohydrate cycle of alpine plants as related to growth. Am. J. Bot., 47: 594-598.

20）宗岡寿美・土谷富士夫・武田一夫・辻 修·伊藤隆広（2001） 法面方位の違いと冬期の気象・地盤環境一寒冷少雪地域に おける法面保全問題 (I) 一, 第 50 回農業土木学会北海道支 部研究発表会講演集, 156-159.

21）中村彰宏・衣笠斗基子 - 陣門泰輔 - 谷口伸二 - 佐藤治雄 · 森本幸裕（2002）埋土種子密度，種数，多様性指数一面積 曲線による森林表土捲き出し緑化の評価, 日本緑化工学会 誌, 28: 73-78.

22）日本緑化工学会（2002）生物多様性保全のための緑化植物 の取り扱い方に関する提言，日本緑化工学会誌，27: 481491.

23）大村理恵子・村中孝司・路川宗夫・鷲谷いづみ（1997）霞ヶ 浦の浚渫土まきだし地に成立する植生，保全生態学研究，
4(1): $1-14$.

24）嶋一徹（2002）特集「緑化工におけるリサイクル」にあ たって，日本緑化工学会誌，27: 555-556.

25) Shimada, T., Genma, T., Furuya, S. and Kondo, Y. (1982) Frost heaving injury of alfalfa. J. Jpn. Grassl. Sci., 28: 147153.

26）嶋田 鐃・川鍋祐夫・佳山良正・伊藤秀三（1973）草地の 生態学, 築地書館, $287 \mathrm{pp}$.

27）土谷富士夫（2004）ヒートパイプによる人工永久凍土低温 貯蔵庫，雪水，66(2): 251-257.

28）梅原 徹・永野正弘（1997）「土を撒いて森を作る!」研究 と事業をふりかえって, 保全生態学研究, 2: 9-26.

29）梅原 徹・永野正弘・麻生順子（1983）森林表土のまきだ しによる先駆植生の回復法, 緑化工技術, 9(3): 1-8.

30）熟谷いづみ・矢原徹一（1996）保全生態学入門, 文一総合 出版, $256 \mathrm{pp}$.

31) Welling, C. H., Pederson, R. L. and Van der Valk, A. G. (1988) Recruitment from the seed bank and the development of zonation of emergent vegetation during a drawdown in a Prairie Wetland. J. Ecol., 76: 483-496.

32）吉永知恵美・亀山 章（1999）埋土種子緑化に関する基礎 的研究一埋土種子の発芽と覆土厚の関係一, 第 19 回道路緑 化技術発表会要旨論文集，18-19.

(2005.2.16 受理) 